\title{
FAKTOR-FAKTOR YANG MEMPENGARUHI PRODUKTIVITAS TENAGA KERJA BURUH PANEN BUAH KELAPA SAWIT(Studi Kasus Pada Divisi I PT. Megasawindo Perkasa IKecamatan Pelepat Kabupaten Bungo)
}

\author{
Fikriman, Arif Herdiansyah \\ Program Studi Agribisnis, Fakultas Pertanian Universitas Muara Bungo, Jambi
}

\begin{abstract}
Research conducted at the Division I Megasawindo PT Perkasa I Sub Pelepat Bungo on December 1, 2015 until January 1, 2016. Selection of the location of this research was done intentionally (purposive sampling) with the consideration that Division I had a workforce of most on the harvesting of coconuts oil with 79 workers to harvest. This study was conducted to determine the factors that affected the productivity of harvest labor of Oil palm fruit in the Division I PT. Megasawindo Mighty I Sub Pelepat Bungo.

The data collection method used in the study was documentation technique that was to obtain data directly from the data of research that palm fruit harvest workers at the Division I PT. Megasawindo Perkasa District of Pelepat many as 79 workers harvest the palm fruits. But the workers must studied the labor of its work effectively during the year 2014 as many as 39 people.

The results showed that the average labor productivity of oil palm fruit harvest workers amounted to 37.31 tons / person / month. Harvest Labor productivity of the palm fruits together significantly affected by factors of wages, work experience, number of dependents and age, it could be seen from the calculated $F$ value (983.312)> F table (2.649), but the partial factor wages were on a very real effect on the productivity of harvest labor of the palm fruits, as seen from the value of $49997 t>t$ table 2,032. While working experience factor, number of dependents and the age factor did not significantly affected harvest labor productivity of oil palm fruit division I PT. Megasawindo Mighty I Sub Pelepat Bungo.
\end{abstract}

\section{Keywords: Productivity, Labor harvest, factors and Palm Oil}

\section{PENDAHULUAN}

Perkebunan merupakan salah satu potensi sub sektor pertanian yang berharga dan digali oleh pemerintah dalam upaya menegakkan perekonomian rakyat dan pembangunan ekonomi Indonesia. Salah satu komoditi perkebunan terpenting dalam perekonomian Indonesia adalah kelapa sawit. Hasil perkebunan kelapa sawit menjadi komoditi strategis sebagai penghasil devisa utama Negara dari sektor nonmigas. Usaha peningkatan produksi perkebunan kelapa sawit diarahkan agar benar-benar dapat berfungsi sebagai penghasil devisa, meningkatkan

\footnotetext{
Alamat korespodensi

Jl. Diponegoro No 27 Muara Bungo

Telp. 0747. 323310

Email : manfikri@ymail.com
}

kesempatan kerja dan meningkatkan pendapatan serta taraf hidup petani (Nainggolan dkk, 2012).

Ditinjau dari segi produksi sawit di Indonesia pada tahun 2013 menghasilkan sebanyak 27.782.004 Ton dengan luas tanam sebesar 10.465.020 ha (BPS RI, 2014) dan untuk Provinsi Jambi sendiri mampu memproduksi kelapa sawit sebanyak 1.749.617 ton dengan luas 657.929. Di Kabupaten Bungo Provinsi Jambi, kelapa sawit juga merupakan salah satu komoditi utama yang diunggulkan selain karet. Adapun produksi sawit pada tahun 2013 yang dihasil adalah sebanyak 163.330 ton dengan luas tanaman sawit 85.673 ha (BPS Provinsi Jambi, 2015).

Beberapa perusahaan perkebunan besar beroperasi di Kabupaten Bungo, baik yang 
dikelola oleh pihak swasta maupun BUMN. Salah satu perusahaan perkebunan tersebut adalah PT. Megasawindo Perkasa I yang terletak di Kecamatan Pelepat. PT. Megasawindo Perkasa I sebagai salah satu perusahaan di Kabupaten Bungo yang memiliki perkebunan kelapa sawit yang cukup besar yaitu 4.273,99 Ha (PT. Megasawindo, 2015), tentunya mempekerjakan tenaga kerja yang cukup besar pula, khususnya untuk kegiatan pemanenan buah sawit. Kegiatan ini secara fungsional mempunyai peranan yang relatif besar karena banyak atau sedikitnya hasil panenan akan sangat menentukan hasil produksi akhir. Dalam hal ini, dapat dikatakan bahwa produksi perusahaan sangat tergantung pada produktivitas kerja dari pemanen sawit itu sendiri.

Tujuan dari penelitian ini adalah : Untuk menganalisis faktor-faktor yang mempengaruhi produktivitas kerja buruh panen buah Kelapa Sawit pada Divisi I PT. Megasawindo Perkasa I Kecamatan Pelepat Kabupaten Bungo.

Tenaga kerja adalah salah satu unsur penentu bagi kegiatan pertanian. Suratiyah (2006) menyatakan bahwa kelangkaan tenaga kerja berakibat mundurnya penanaman sehingga berpengaruh pada pertumbuhan tanaman, produktivitas dan kualitas produk. Pada perusahaan pertanian, peranan tenaga kerja belum sepenuhnya dapat diatasi dengan teknologi yang menghemat tenaga (teknologi mekanis). Hal ini dikarenakan selain mahal, juga ada hal-hal tertentu yang memang tenaga kerja manusia tidak dapat digantikan. Hal-hal yang mempengaruhi tenaga kerja dalam bekerja yaitu sistem upah yang diterima para pekerja. Sistem upah terdiri dari sistem borongan sesuai perjanjian pemberi kerja dengan pekerja, sistem waktu yang berdasarkan lamanya waktu pekerja, dan upah premi dengan memperhatikan produktivitas dan prestasi kerja.

a. Lamanya waktu bekerja.

b. Kehidupan sehari-hari pekerja yang dapat dilihat dari makanan, gizi, perumahan, kesehatan serta keadaan lingkungan.

c. Kecakapan dalam bekerja

d. Umur tenaga kerja, sehingga menentukan prestasi kerja seseorang.
Menurut Hadisapuetro (1973) dalam Ardiansyah (2009), besarnya prestasi kerja tenaga kerja keluarga dipengaruhi oleh perbandingan antara besarnya konsumen (pemakai) dalam keluarga dengan jumlah tenaga kerja yang tersedia.

Produktivitas menurut Sudomo (1993), mempunyai berbagai pengertian terpenting sebagai berikut :

1. Produktivitas ialah rasio dari apa yang dihasilkan (output) terhadap keseluruhan faktor produksi yang digunakan (input).

2. Dewan Produktivitas Nasional Indonesia merumuskan produktivitas sebagai berikut : Produktivitas pada dasarnya adalah sesuatu sikap mental yang selalu mempunyai pandangan bahwa mutu kehidupan hari ini harus lebih baik dari kemarin dan hari esok lebih baik dari hari ini.

3. Produktivitas mengikutsertakan pendayagunaan secara terpadu sumber daya manusia dan ketrampilan barang modal, teknologi, manajemen, informasi, energy dan sumber-sumber lain menuju kepada pengembangan dan peningkatan standar hidup untuk seluruh masyarakat melalui konsep produktivitas semesta/total.

4. Produktivitas adalah kekuatan pendorong (driving force) untuk mewujudkan kualitas hidup, pertumbuhan ekonomi dan kemajuan sosial yang pada hakekatnya adalah sasaran pembangunan nasional. Dengan perkataan lain produktivitas mendorong pertumbuhan dan pertumbuhan adalah kemajuan. Untuk suatu negara ukurannya adalah Gross Domestik Bruto (GDB) sedangkan untuk perorangan diukur dengan jam kerja (input per man hour).

Secara global atau umum produktivitas bisa dikatakan sebagai hasil dari kegiatan atau pekerjaan yang telah dilakukan dengan seluruh sumber daya yang digunakan untuk menghasilkan sesuatu yang ingin dicapai. Menurut Kussriyanto (1986) produktivitas adalah sikap mental terhadap kemajuan dan kehidupan. Lalu juga dikatakan bahwa tenaga kerja dijadikan faktor pengukur suatu produktivitas produktivitas. Hal ini disebabkan karena biaya untuk tenaga kerja merupakan biaya terbesar dalam pengadaan produk dan 
masukan dalam sumberdaya manusia lebih mudah dihitung daripada masukan pada faktorfaktor lainnya.

\section{Menurut Simanjuntak}

produktivitas mengandung pengertian filosofis dan kuantitatif. Secara filosofis produktivitas mengandung arti pandangan hidup dan sikap mental yang selalu berusaha untuk meningkatkan mutu kehidupan. Keadaan hari ini harus lebih baik daripada kemaren, dan mutu kehidupan besok harus lebih baik daripada hari ini. Secara kuantitatif, produktivitas merupakan perbandingan antara hasil yang ingin dicapai (keluaran) dengan kesuluruhan sumber daya (masukan) yang digunakan per satuan waktu.

Suatu peningkatan produktivitas pegawai dapat diketahui apabila kemampuan kita dalam bekerja lebih baik dari kemarin, lebih bagus dari kemarin serta mampu bekerja lebih baik dari kemarin, lebih bagus dari kemarin serta mampu bekerja secara efisien dan efektif maka bisa dikatakan produktivitas kita dalam kerja meningkat.

Cara pengukuran produktivitas tenaga kerja dapat dilakukan dengan berbagai pendekatan (Widodo, 1989)

$$
\begin{aligned}
& \text { Produktivitas Tenaga Kerja }=\frac{\text { Jumlah Hasil Produksj }}{\text { Satuan Waktu }} \\
& \text { Atau } \quad \text { Produktivitas }=\frac{\text { Jumlah Yang Dihasilkan }}{\text { Jumlah masukan tenaga kerja }}
\end{aligned}
$$

Sedangkan tujuan diadakannya pengukuran produktivitas antara lain untuk membandingkan hasil - hasil :

1. Pertumbuhan produksi dari waktu ke waktu.

2. Pertumbuhan pendapatan dari waktu ke waktu

3. Pertumbuhan kesempatan kerja dari waktu ke waktu.

Produktivitas tenaga kerja dipengaruhi oleh berbagai faktor, baik yang berhubungan dengan tenaga kerja itu sendiri maupun faktor lain seperti pendidikan, keterampilan, displin sikap dan etika kerja, motivasi, gizi dan kesehatan, tingkat penghasilan, jaminan sosial, lingkungan dan iklim kerja teknologi, sarana produktivitas, manejemen dan kesempatan berprestasi (Kusriyanto, 1986).

\section{METODOLOGI PENELITIAN}

Penelitian dilaksanakan di Divisi I PT Megasawindo Perkasa I Kecamatan Pelepat Kabupaten Bungo pada tanggal 01 Desember 2015 sampai 01 Januari 2016. Pemilihan lokasi penelitian ini dilakukan secara sengaja (purposive sampling) dengan pertimbangan bahwa Divisi I merupakan divisi sentral, mempunyai topograpi lahan yang datar dan tanaman yang homogen (tahun tanam sama) dan mempunyai tenaga kerja yang paling banyak pada bagian pemanenan buah kelapa sawit.

PT. Megasawindo yang terdiri dari 4 divisi. Dari 4 divisi dipilih satu divisi yaitu divisi I sebagai sampel dengan alasan bahwa pada divisi I tersebut adalah divisi sentral, mempunyai topograpi lahan yang datar dan tanaman yang homogen (tahun tanam sama). Metode pengambilan data yang digunakan adalah teknik dokumentasi yaitu dengan memperoleh data langsung dari tempat penelitian yaitu data buruh panen buah sawit pada Divisi I PT. Megaswindo Perkasa Kecamatan Pelepat sebanyak 79 buruh panen buah sawit. Namun buruh yang akan diteliti adalah buruh yang masa kerjanya efektif selama tahun 2014 yaitu sebanyak 39 orang.

Untuk mengetahui pengaruh upah, pengalaman kerja, jumlah tanggungan keluarga dan umur terhadap tingkat produktivitas maka digunakan metode analisis regresi linier berganda dengan menggunakan program SPSS karena program tersebut lebih mudah diaplikasikan dan dianalisis oleh penulis. Menurut Soekartawi (2000), secara matematis dapat ditulis sebagai berikut :

$\mathbf{Y}=\mathbf{a}+\mathbf{b}_{1} \mathbf{X}_{1}+\mathbf{b}_{2} \mathbf{X}_{2}+\mathbf{b}_{3} \mathbf{X}_{3}+\mathbf{b}_{4} \mathbf{X}_{4}+\mathbf{e}$

Keterangan:

$\mathrm{Y}=$ Produktivitas (ton/orang/bulan)

$\mathrm{X}_{1} \quad=\operatorname{Upah}(\mathrm{Rp} / \mathrm{bulan})$

$\mathrm{X}_{2} \quad=$ Pengalaman Kerja (Tahun)

$\mathrm{X}_{3} \quad=$ Jumlah Tanggungan Keluarga (orang)

$\mathrm{X}_{4} \quad=$ Umur (tahun)

a $\quad=$ Intersep

$b_{1} . . b_{4}=$ Koefisien regresi dari $X_{1}, X_{2}, X_{3}$

Untuk mengetahui besarnya proporsi atau presentase variasi total produktivitas yang dijelaskan oleh setiap variabel secara bersamasama, digunakan koefisien determinasi $\left(\mathrm{R}^{2}\right)$ 
dengan rumus :

$\mathrm{R}^{2}=\frac{\mathrm{bi} \sum \mathrm{XiYi}}{\sum \mathrm{Yi}^{2}}$

Dimana :

$\mathrm{R}^{2} \quad=$ Koefisien determinasi berganda antara Yi dengan $\mathrm{Xi}$

bi $\quad=$ Koefisien regresi ke-i

$\mathrm{Yi}^{2} \quad=$ Kuadrat simpangan suatu variable ke-I dari nilai rata-rata $(\mathrm{Yi}-\mathrm{Y})^{2}$

$\mathrm{Xi}=$ Variabel deviasi ke-i dari rata-rata $(\mathrm{Xi}-\mathrm{X})$

$\mathrm{Yi} \quad=$ Simpangan suatu variabel dari nilai rata-rata $(\mathrm{Yi}-\mathrm{Y})$

Untuk pengujian kebenaran dari seluruh variabel digunakan pengujian F-test, Nilai dihitung dengan rumus :

$$
\mathrm{F}_{\text {hitung }}=\frac{\mathrm{R}^{2} / \mathrm{k}}{\left(1-\mathrm{R}^{2}\right) /(\mathrm{n}-\mathrm{k} 1)}
$$

Dimana :

$\mathrm{R}^{2} \quad=$ Koefisien Determinasi

$\mathrm{k}=$ Jumlah variabel

$\mathrm{n} \quad=$ Jumlah sampel

Jika $\mathrm{F}_{\text {hitung }}>\mathrm{F}_{\text {table }}$ berarti $\mathrm{H}_{0}$ ditolak, artinya secara simultan variabel dependen mempengaruhi variabel independen

Jika $\mathrm{F}$ hitung $\leq \mathrm{F}$ tablel berarti $\mathrm{H}_{0}$ diterima, artinya secara simultan variabel dependen tidak mempengaruhi variabel independent dan (Sudjana, 2005) berikut :

Sedangkan untuk Uji Parsial digunakan Uji T, (Sudjana, 2005) dengan rumus sebagai

$$
\mathrm{Ti}=\frac{\mathrm{bi}}{\mathrm{Sbi}}
$$

Dimana :

$\mathrm{Ti} \quad=\mathrm{t}$-hitung

bi $\quad=$ Koefisien regresi variabel ke -1

Sbi = Standar error masing-masing variabel ke-1

Jika $\mathrm{t}$ hitung $\leq \mathrm{t}$ table berarti $\mathrm{H}_{1}$ ditolak, artinya secara parsial variabel dependen tidak mempengaruhi variabel independen

Jika $\mathrm{t}_{\text {hitung }}>\mathrm{t}$ tablel berarti $\mathrm{H}_{1}$ diterima, artinya secara parsial variabel dependen mempengaruhi variabel independen (Sudjana, 2005)

\section{HASIL}

\section{Karakteristik Responden}

Identitas buruh panen buahkelapa sawit yang akan di bahas meliputi umur, pengalaman kerja, jumlah tanggungan keluarga dan upah yang diterima buruh panen.

\section{Umur}

Umur mempengaruhi kemampuan fisik dan cara berfikir seseorang buruh. Secara umum dapat dikatakan bahwa buruh yang berusia muda dan sehat fisik maupun mentalnya akan memiliki kemampuan fisik dan produktivitas yang lebih tinggi. Berdasarkan hasil penelitian tingkat umur responden berada antara 20 sampai 57 tahun (Lampiran 1). untuk lebih jelasnya distribusi frekuensi umur responden dapat di lihat Tabel 1.

Dari Tabel 1 di atas dapat dikatakan bahwa sebagian besar responden berada pada kelompok umur 31 - 40 tahun sebesar 43,59\% kemudian diikuti kelompok umur 41 - 50 tahun sebesar $30,77 \%$ dan kelompok umur $20-30$ tahun sebesar 17,95\%, dan kelompok umur $>$ 51 tahun merupakan kelompok umur yang paling sedikit yaitu 7 orang $(7,69 \%)$, dengan demikian jumlah buruh panen berada dalam kelompok umur yang produktif artinya buruh panen tersebut masih memiliki fisik yang kuat dan semangat kerja yang tinggi dalam rangka mengembangkan potensi usaha produksi mereka 
dalam bekerja dan pencapaian target yang telah ditentukan oleh perusahaan. Hal ini sesuai yang diungkapkan Herawati (2013), semakin bertambahnya umur maka akan semakin produktif, karena dianggap memiliki pengalaman kerja yang lebih banyak dibanding dengan yang masih muda. Kecuali tenaga kerja yang memasuki masa pensiun

\section{Tabel 1. Distribusi Frekuensi Responden Berdasarkan Umur}

\begin{tabular}{ccc}
\hline $\begin{array}{c}\text { Umur } \\
\text { (Tahun) }\end{array}$ & Jumlah Responden (Orang) & Persentase (\%) \\
\hline $20-30$ & 7 & 17,95 \\
$31-40$ & 17 & 43,59 \\
$41-50$ & 12 & 30,77 \\
$>51$ & 3 & 7,69 \\
\hline Jumlah & 39 & 100,00 \\
\hline
\end{tabular}

Sumber : Hasil Penelitian 2015

\section{Pengalaman Kerja}

Dalam penelitian ini, lama buruh panen bekerja di perusahaan dihitung sejak buruh panen tersebut diangkat menjadi buruh panen buah sawit di tempat penelitian. Berdasarkan hasil penelitian pengalaman kerja responden berada antara 2 sampai 14 tahun. Untuk melihat distribusi frekuensi responden berdasarkan pengalaman bekerja dapat dilihat pada Tabel 2 berikut.

Tabel 2. Distribusi Frekuensi Responden Berdasarkan Pengalaman Kerja

\begin{tabular}{ccc}
\hline Pengalaman Kerja (Tahun) & Jumlah Responden (Orang) & Persentase (\%) \\
\hline$<6$ & 20 & 51,28 \\
$6-10$ & 15 & 38,46 \\
$>11$ & 4 & 10,26 \\
\hline Jumlah & 39 & 100,00 \\
\hline
\end{tabular}

Sumber : Hasil Penelitian 2015

Bila dilihat berdasarkan Tabel 2 di atas dapat dilihat responden yang memiliki pengalaman kerja selama $<6$ tahun adalah 20 orang $(51,28 \%)$, sedangkan responden yang memiliki pengalaman bekerja mulai dari 6-10 tahun adalah sebanyak 15 orang $(38,46 \%)$, dan responden yang memiliki pengalaman bekerja di atas 11 tahun adalah sebanyak 4 orang $(10,26$ $\%)$.

Pengalaman akan mempengaruhi kemahiran buruh panen dalam bekerja.
Semakin mahir maka akan semakin meningkatkan produktifitas kerja sehingga jumlah produksi buah sawit dapat dipanen dalam jumlah yang besar pula. Hal ini sesuai dengan pernyataan Amron, 2009 dalam Adhadika (2013) bahwa semakin banyak pengalaman yang didapatkan oleh seorang pekerja akan membuat pekerja semakin terlatih dan terampil dalam melaksanakan pekerjaannya.

Jumlah Tanggungan Keluarga 
Jumlah tanggungan keluarga yang dimaksud dalam penelitian ini adalah semua orang yang tinggal dalam satu rumah atau jumlah jiwa yang kebutuhan fisik dan batinnya menjadi tanggungan buruh. Besarnya jumlah tanggungan keluarga akan mendorong buruh untuk bekerja lebih giat guna memenuhi kebutuhan hidup anggota keluarga tersebut. Distribusi responden berdasarkan jumlah tanggungan pada responden dapat dilihat pada tabel sebagai berikut.

Tabel 3. Distribusi Frekuensi Responden Berdasarkan Jumlah Tanggungan Keluarga

\begin{tabular}{ccc}
\hline Jumlah Tanggungan (Orang) & Jumlah Responden (Orang) & Persentase (\%) \\
\hline $0-2$ & 22 & 56,41 \\
$3-5$ & 17 & 43,59 \\
\hline Jumlah & 39 & 100,00
\end{tabular}

Sumber : Hasil Penelitian 2015

Dari Tabel 3 menunjukkan bahwa jumlah tanggungan keluarga responden yang terbanyak yaitu pada interval kelas $0-2$ orang yaitu sebanyak 22 orang $(56,41 \%)$, sedangkan jumlah terkecil berada pada interval kelas $2-5$ orang yaitu sebanyak 17 orang responden $(43,59 \%)$. Menurut Hernanto (1989), bahwa seseorang yang mempunyai jumlah tanggungan yang lebih besar akan diburu oleh kebutuhan keluarga, dengan demikian ia akan berusaha semaksimal mungkin untuk memenuhi kebutuhannya.

Upah

Distribusi frekuensi rata-rata upah yang diterima respoden setiap bulannya dapat dilihat pada Tabel 4 berikut.

Tabel 4. Distribusi Frekuensi Responden Berdasarkan Upah

\begin{tabular}{ccc}
\hline $\begin{array}{c}\text { Rata-rata Upah } \\
(\text { Rp/Bulan })\end{array}$ & $\begin{array}{c}\text { Jumlah Responden } \\
\text { (Orang) }\end{array}$ & Persentase (\%) \\
\hline $1.000 .000-1.500 .000$ & 1 & 2,56 \\
$1.500 .001-2.000 .000$ & 8 & 20,52 \\
$2.000 .001-2.500 .000$ & 20 & 51,28 \\
$>2.500 .000$ & 10 & 25,64 \\
\hline Jumlah & 39 & 100,00
\end{tabular}

Sumber : Hasil Penelitian 2015

Berdasarkan hasil penelitian, upah ratarata yang diterima responden adalah $\mathrm{Rp}$. 2.260.364 per bulan (lampiran 1), dengan range (Rp 1.167.606 - Rp 2.890.994). Berdasarkan Tabel 4 dapat dilihat bahwa sebanyak 20 orang $(51,828 \%)$ responden menerima upah pada interval $\mathrm{Rp} 2.001 .000$ - Rp 2.500.000 per bulan dan diiukuti oleh responden yang menerima upah pada inetrval diatas $\mathrm{Rp} 2.500 .000$ per bulan diterima oleh 10 orang $(25,64 \%)$ dan upah pada sebanyak 8 orang $(20,51 \%)$ responden menerima upah pada interval $\mathrm{Rp}$ 1.500.001 - Rp 2.000.000 dan hanya 1 orang responden $(2,56 \%)$ yang menerima upah pada interval $\mathrm{Rp} 1.000 .000$ - Rp 1.500 .000 per bulannya.

Semakin banyak produksi yang dihasilkan responden dalam melakukan pemanenan sawit semakin banyak upah yang diterima responden setiap bulan, karena upah yang diterima oleh responden ditentukan oleh jumlah produksi buah sawit yang di panen 
setiap bulannya.

Produktivitas Buruh panen Buah Kelapa Sawit Pada Divisi I PT Megasawindo

Produktivitas tenaga kerja adalah perbandingan jumlah produksi yang dicapai setiap satuan waktu. Adapun data produktivitas yang diperoleh berupa data jumlah buah kelapa sawit yang dipanen oleh responden setiap bulannya di Divisi I PT. Megasawindo Perkasa I Kecamatan Pelepat pada tahun 2014. Untuk melihat produktivitas tenaga kerja responden pada daerah penelitian berdasarkan produksi yang dihasilkan responden per bulan (Ton/orang/bulan) dapat dilihat pada tabel berikut ini :

Tabel 5. Distribusi Frekuensi Responden Berdasarkan Produktivitas

\begin{tabular}{ccc}
\hline Produktivitas (Ton/Orang/Bulan) & $\begin{array}{c}\text { Jumlah Responden } \\
\text { (Orang) }\end{array}$ & Persentase (\%) \\
\hline $20-30$ & 7 & 17,95 \\
$31-40$ & 21 & 53,85 \\
$>41$ & 11 & 28,20 \\
\hline Jumlah & 39 & 100,00 \\
\hline
\end{tabular}

Sumber : Hasil Penelitian, 2015

Berdasarkan hasil penelitian, rata-rata produkstivitas kerja responden perbulannya adalah 37.31 ton per bulan, dengan range $(20,48$ ton/orang/bulan - 47.57 ton/orang/bulan) (Lampiran 2). Berdasarkan Tabel 5 dapat dilihat bahwa sebanyak 21 orang $(53,85 \%)$ responden mempunyai produktivitas pada interval $31-40$ ton/orang/bulan dan 11 orang $(28,21 \%)$ responden mempunyai produktivitas pada interval diatas 41 ton/orang/bulan dan hanya 7 orang $(17,95 \%)$ yang mempunyai produktivitas inetrval $20-30$ ton/orang/bulan.

\section{Analisis Faktor-Faktor Yang Mempengaruhi Produktivitas Tenaga Kerja Buruh panen Buah Kelapa Sawit}

Untuk mengetahui seberapa besar pengaruh Upah, Pengalaman Kerja, Jumlah Tanggungan Keluarga dan Umur terhadap produktivitas tenaga kerja Responden dapat dilihat pada tabel berikut ini :

Tabel 6. Analisis Regresi pengaruh Upah, Pengalaman Bekerja, Jumlah Tanggungan dan Umur terhadap produktivitas Tenaga Kerja Responden.

\begin{tabular}{lcccc}
\hline Variabel & $\begin{array}{c}\text { Koefisien } \\
\text { Regresi }\end{array}$ & $\begin{array}{c}\text { Standar } \\
\text { Error }\end{array}$ & t hitung & Sig. \\
\hline Konstanta & 2.026 & .961 & 2.108 & .42 \\
Upah (Rp/Bulan) & 15.779 & .361 & 49.997 & .000 \\
Pengalaman Kerja (Tahun) & .002 & .033 & .075 & .941 \\
Jumlah Tanggungan (Orang) & .098 & .103 & .952 & .341 \\
Umur (Tahun) & -.016 & .014 & -1.163 & .253 \\
\hline $\mathrm{R}^{2}$ & 0,991 & $\mathrm{t}$ tabel $=2,032$ & \\
\hline F table & 2,649 & & \\
\hline F hitung & 983.312 &
\end{tabular}

Pada Tabel 6 terlihat bahwa nilai $\mathrm{F}$ hitung $(983,312)>$ nilai $\mathrm{F}$ tabel $(2,649)$ yang artinya bahwa variabel independent (upah, pengalaman kerja, jumlah tanggungan dan umur) berpengaruh secara bersama-sama terhadap produktivtas tenaga kerja yang diperoleh. Hal ini juga didukung dengan diketahuinya nilai koefisien determinasi $\left(\mathrm{R}^{2}\right)$ sebesar 0,991 yang 
artinya bahwa variabel independen (faktor yang mempengaruhi produktivitas) yang digunakan dalam model mampu menjelaskan variabel dependen (produktivitas) sebesar 99,1 \% sedangkan sisanya $0,9 \%$ produktivitas tenaga kerja buruh sawit di Divisi I PT Megasawindo Perkasa I dipengaruhi oleh faktor lain di luar model. Persamaan regresi yang diperoleh dari hasil analisis model fungsi produksi Cobb Douglas adalah

$$
\mathrm{Y}=2.026+15.779 \mathrm{X}_{1}+0,002 \mathrm{X}_{2}+.098 \mathrm{X}_{3}-0,016 \mathrm{X}_{4}
$$

Dari penyajian persamaan diatas diketahui bahwa hubugan $X_{1}, X_{2}$ dan $X_{3}$ (upah, pengalaman kerja dan jumlah tanggungan) terhadap produktivitas tenaga kerja buruh panen sawit adalah positif yang berarti meningkat atau naik. Nilai variabel diatas menyebabkan peningkatan produktivitas sawit, sedangkan $\mathrm{X}_{4}$ (umur), adalah hubungan negatif. Dari persamaan di atas juga diketahui nilai intersep sebesar 2.026. Selanjutnya untuk mengetahui pengaruh masing-masing variabel independen (X) terhadap variabel dependen (Y) dilakukan analisis parsial uji t terhadap koefisien regresi.

\section{Upah (Rp/Bulan)}

Dari hasil analisis didapat nilai koefisien regresi 15.779 dan nyata pada taraf kepercayaan $95 \%$ hal ini terlihat dari nilai t hitung $49.997>\mathrm{t}$ tabel 2,032. Artinya bahwa jika variabel lain dianggap konstan, maka apabila terjadi penambahan upah satu rupiah maka produktivitas tenaga kerja pemanen akan meningkat sebesar 15,779 ton/orang/bulan. Dengan lebih besarnya nilai $t$ hitung dari nilai $t$ tabel maka $\mathrm{H}_{1}$ diterima dan Ho ditolak, artinya upah berpengaruh sangat nyata terhadap produktivitas tenaga kerja buruh panen kelapa sawit divisi I PT Megasawindo Perkasa. Hal ini disebabkan oleh tingkat upah yang diberikan pada buruh panen sawit sudah sesuai dan cocok dengan produksi panen yang dihasilkan. Hal ini sesuai dengan pendapat Kurniawan dalam Vellina dan Nenik, (2010) yang menyatakan bahwa upah yang wajar adalah upah yang memungkinkan pekerja untuk memenuhi kebutuhannya secara manusiawi, sehingga ketika tingkat penghasilan cukup, akan menimbulkan konsentrasi kerja dan mengarahkan kemampuan yang dimiliki untuk meningkatkan produktivitas.

\section{Pengalaman Kerja (Tahun)}

Dari hasil analisis didapatkan nilai t- hitung untuk variabel pengalaman kerja adalah sebesar 0.075 dan nilai $\mathrm{t}$ tabel adalah 2,032. Nilai t-hitung berada pada daerah terima Ho dan tolak $\mathrm{H}_{1}$ yang berarti bahwa pengalaman kerja secara individu tidak berpengaruh terhadap produktivitas tenaga kerja buruh panen sawit. Hal ini dikarenakan, pengalaman kerja buruh panen buah kelapa sawit di divisi I masih kurang atau sedikit yaitu sebanyak 51,28\% buruh masih berpengalaman kurang dari 6 tahun. Masih kurangnya atau sedikitnya pengalaman kerja buruh panen di tempat penelitian berakibat pada produktivitas kerja karena semakin lama pengalaman kerja buruh panen akan semakin mudah dalam menyelesaikan suatu produk dan semakin kurang berpengalaman kerja buruh panen buah kelapa akan mempengaruhi kemampuan berproduksi buruh panen dalam menyelesaikan pekerjaan memanen buah kelapa sawit sehingga dapat dikatakan buruh panen yang lebih yang banyak pengalaman akan mudah dalam menghadapi masalah-masalah yang terjadi saat memanen dan lebih tinggi produktivitas kerjanya.

\section{Jumlah Tanggungan Keluarga (Orang)}

Koefisien regresi jumlah tanggungan keluarga yang digunakan pada analisis yang terdapat pada Tabel 7 adalah sebesar 0,098 dan terlihat nilai $t$ hitung $(0,952)<\mathrm{t}$ tabel $(2,032)$, sehingga Ho diterima dan H1 ditolak. Berarti bahwa jumlah tanggungan keluarga tidak berpengaruh nyata terhadap produkstivitas tenaga kerja buruh panen sawit. Hal ini diduga dipengaruhi oleh jumlah tanggungan keluarga pada buruh panen sedikit sehingga buruh panen tidak termotivasi untuk meningkatkan kinerjanya untuk memenuhi kebutuhan hidup atau beban tanggungannya. Jumlah tanggungan semakin banyak menekankan akan adanya lahan tanaman yang luas untuk membiayai kebutuhan 
keluarganya. Menurut Hernanto (1989) bahwa petani yang mempunyai jumlah tanggungan lebih besar akan diburu oleh kebutuhan keluarga. Dengan demikian ia akan berusaha semaksimal mungkin untuk memenuhi kebutuhannya.

Selain itu jumlah tanggungan keluraga pada buruh panen tidak memberikan kontribusi terhadap pekerjaan memanen sawit karena pekerjaan memanen sawit merupakan kegiatan yang cukup berat dan sulit, apalagi jika kelapa sawit yang dipanen batangnya sudah tinggi. Penelitian Subagio (2011) juga mengatakan bahwa semakin banyak tanggungan keluarga, semakin banyak ketersediaan tenaga kerja untuk usahatani. Apabila tanggungan keluarga tersebut tidak dapat menyumbangkan tenaganya, maka akan berdampak negatif terhadap usahataninya. Anggota keluarga yang tidak menyumbangkan tenaganya akan menjadi beban bagi petani.

\section{Umur (Tahun)}

Dalam analisis regresi diperoleh nilai koefisien regresi sebesar $-0,016$ dan nilai $t$ hitung $(-1,163)<\mathrm{t}$ tabel $(2,032)$ sehingga Ho diterima dan tolak H1. Berarti bahwa umur buruh panen sawit tidak berpengaruh nyata terhadap produktivitas tenaga kerja buruh sawit. Selain itu, jika variabel lain dianggap konstan, maka pada setiap penambahan satu satuan umur akan menyebabkan penurunan produktivitas kerja sebesar 0,016 ton/orang/bulan. Hal ini karena produktivitas kerja hanya sampai batas umur tertentu saja dimana selanjutnya jika umur bertambah maka produktivitas menurun. Penurunan ini disebabkan oleh kondisi fisik dan kesehatan akan menurun seiring bertambahnya umur sehingga berdampak menurunnya produktivitas kerja.

\section{KESIMPULAN}

Rata-rata produktivitas tenaga kerja buruh panen buah sawit adalah sebesar 37,31 ton/orang/bulan.

Produktivitas tenaga kerja buruh panen buah sawit secara bersama-sama nyata dipengaruhi oleh faktor upah, pengalaman kerja, jumlah tanggungan keluarga dan faktor umur, hal ini dapat dilihat dari nilai $\mathrm{F}$ hitung $(983,312)$ $>$ nilai $F$ tabel $(2,649)$, namun secara parsial faktor upah yang memberikan pengaruh nyata terhadap produktivitas tenaga kerja buruh panen buah sawit, hal ini terlihat dari nilai t hitung $49.997>\mathrm{t}$ tabel 2,032. Sedangkan faktor pengalaman kerja, jumlah tanggungan keluarga dan faktor umur tidak berpengaruh secara nyata terhadap produktivitas tenaga kerja buruh panen buah sawit PT. Megasawindo Perkasa I Kecamatan Pelepat Kabupaten Bungo.

\section{Daftar Pustaka}

Adhadika, T. 2013. Analisis Faktor-Faktor Yang Mempengaruhi Produktivitas Tenaga Kerja Industri Pengolahan Di Kota Semarang. Fakultas Ekonomika Dan Bisnis Universitas Diponegoro. Semarang.

Ardiansyah. 2009. Faktor-Faktor Yang Berhubungan Dengan Produktivitas Kerja Petani Kebun Plasma Kelapa Sawit (Studi Kasus Kebun Plasma PTP. Mitra Ogan, Kecamatan Peninjauan, Sumatra Selatan) Departemen Agribisnis Fakultas Ekonomi Dan Manajemen Institut Pertanian Bogor. BogorBPS Provinsi Jambi. 2015. Jambi Dalam Angka 2015. http://jambi.bps.go.id. Diunduh 09 November 2015.

BPS Republik Indonesia. 2014. Statistik Kelapa Sawit Indonesia 2014. http://www.bps.go.id. Diunduh 09 November 2015.

Herawati, N. 2013. Analisis Pengaruh Pendidikan, Upah, Pengalaman Kerja, Jenis Kelamin, dan Umur Terhadap Produktivitas Tenaga Kerja Industri Shutllecock Kota Tegal. Skripsi. Semarang: Fakultas Ekonomika dan Bisnis Universitas Diponegoro Semarang.

Hernanto F. 1989. Ilmu Usahatani. Penebar Swadaya. Jakarta.

Kussriyanto, B. 1986. Meningkatkan Produktivitas Karyawan. PT. Pustaka Binaman Pressindo. Jakarta.

Nainggolan, R., Agus P dan Zulkarnain. M. Y. 2012. Faktor-faktor yang Mempengaruhi Produktivitas Tenaga Kerja Pemanen Sawit pada PT. Bio Nusantara Teknologi, Bengkulu. Jurnal Agrisep Volume 11 No. 1.

Simanjuntak, P.J. 1985. Pengantar Ekonomi Sumber Daya Manusia. Jakarta: LP - 
Soekartawi. 2000. Prinsip Dasar Ekonomi Pertanian. Teori dan Aplikasi. Rajawali Press. Jakarta.

Subagio, H. C. NM. 2011. Hubungan Karakteristik Petani dengan Usahatani Cabai sebagai Dampak dari Pembelajaran FMA (Studi Kasus di Desa Sunju Kecamatan Marawola Provinsi Sulawesi Tengah). Balai Pengkajian Teknologi Pertanian Sulawesi Tengah.

Sudjana. 2005. Metoda Statistika. Tarsito. Bandung.

Sudomo. 1993, Manajemen Indonesia, Pustaka Binawan Pressindo. Jakarta.

Suratiyah, K. 2006. Ilmu Usaha Tani. Penebar Swadaya. Jakarta.

Vellina, T dan Nenik. W. 2010. Analisis Pengaruh Pendidikan, Upah, Insentif, Jaminan Sosial dan Pengalaman Kerja Terhadap Produktivitas Tenaga Kerja Di Kota Semarang (Studi Kasus Kecamatan Banyumanik dan Kecamatan Gunungpati). Jurnal Ekonomi Diponegoro. Semarang: Program Sarjana Fakultas Ekonomika dan Bisnis Universitas Diponegoro.

Widodo, U.W. 1989. Produktivitas Tenaga Kerja, Jurnal Lintasan Ekonomi Volume 6. No. 2. 